\title{
$t$-ブチルフェロセン類の酸化反応に対する置換基の立体効果 および溶媒効果1)2
}

(1995 年 7 月 10 日受理)

\author{
林隆俊·岡田豊*.山下哲朗
}

フェロセンと $1,1^{\prime}, 3,3^{\prime}-$ テトラ-t-ブチルフェロセンの空気酸化の反応性を，トリクロロ酢酸存在下数 種の溶媒中で測定した．八ロアルカン溶媒中での酸化反応では， $t$-ブチル基のI-効果が支配的であっ た. 一方, 含酸素溶媒中では, $t$-ブチル基による反応抑制効果が観察された．これは，触媒プロトンが 含酸素溶媒により溶媒和され，かさ高くなる．そのため，プロトンがフェロセン核の鉄原子を攻撃する 際に $t$-ブチル基による立体障害をうけ，反応が抑制されるためと推察された.

\section{1 緒 言}

著者らは, 最近いくつかのフェロセン $(\mathrm{Fc})$ 誘導体の酸化反応 性について報告しだ3)：1,2-ジクロロエタン中での $t$-ブチルフ エロセン類の反応性は, 鉄原子へのプロトンの配位の起こりやす さに支配されていだ)。この場合, 反応は式(1)により進行し た5). 他方，1,4-ジオキサンのようなエーテル系溶媒中では， $\mathrm{Fc}$ とt-ブチルフェロセンの反応性は, 反応の途中で急激に増加 した.これは, Fc やt-ブチルフェロセンでは, シクロペンタジ エニル環が十分な電子供与能力をもたないため, 生成したフェロ セニウムイオンが不安定となり, 分解を起こした結果, $\mathrm{Fe}^{3+}$ イ オンが生成し，これが未反応の Fc 類を強く酸化させるためであ ることを明らかにしだ).

ここで認められた反応率の急激な増加は, Fc とt-ブチルフェ ロセンに対してのみみられたものであり, 二つ以上の $t$-ブチル 基をもつ多置換体に対しては観察されなかった，すなわち，これ らの多置換誘導体の酸化反応は，1,2-シクロロエタン中での反応 と同様に，式(1)にしたがって進行していると考えられた4)。 た， Fc とt-ブチルフェロセンにおいても，反応率の急激な增加 が始をる(反応開始からそれぞれ 1,3 時間) むでは, 反応は式 (1) にしたがって進行しているとみなされた。

フェロセニル基上の $t$-ブチル基は, 電子供与性であるため6), 鉄原子の電子密度を増大させ, 式(1)にしたがう酸化反応性を 増大させると考えられる。事実, 1,2-ジクロロエタン中での実験 結果は, $t$-ブチル基数の增加とともに酸化反応を促進させている ことを示していだ)。一方， $t$-ブチル基は比較的かさ高い基であ ク，これによる立体障害は多くの有機化学反応に対し報告されて いる7).このような立体障害が $t$-ブチルフェロセン類の酸化反応 に対しみられるかどうかは興味深いところである. そこで, 著者 らは, $t$-ブチルフェロセン類の酸化反応を種々の溶媒中で行い, tーブチル基による I-効果および立体効果の影響を検討した.

\section{2 実験}

\section{1 試料の合成}

$t$-ブチルフェロセン類は，既知の方法8) 10) で合成した ${ }^{11) 。 す ~}$ べての誘導体は, 融点, ${ }^{1} \mathrm{H}-\mathrm{NMR}$ および HPLC により同定し, 純粋であることを確認した．合成した誘導体の融点および ${ }^{1} \mathrm{H}-$ NMR の化学シフトのデータは既報11)に示した.

\section{2 酸化反応および分析}

酸化反応および分析は既報344)に示したのと同一の方法で行っ た.すなわち, 反応装置は, 小型三つロフラスコに還流冷却器, 温度計および側管付き滴下漏斗を備えたものを使用し，空気は滴 下漏斗の頭部から導入した．このフラスコに Fc または $t$-ブチル フェロセン類 $0.3 \mathrm{mmol}$ と溶媒 $50 \mathrm{ml}$ を投入し, 滴下漏斗から所 定量のトリクロロ酭酸を溶媒 $10 \mathrm{~m} l$ に溶かしたものをすげやく 滴下し，滴下終了時を反応開始時間とした．反応混合物は一定時 間ごとにサンプリングし，水中に投じ，よくかきまぜて反応を停 止させた．有機層と水層に分離した(水と混さる溶媒を用いたと きは，1,2-シクロロエタンを抽出溶媒として用いた)．この時， 酸化生成物は水層に移るので, 有機層の HPLC 分析により未反 応の基質量から反応物量を求めた. 反応速度定数は $\mathrm{Fc}$ 誘導体に 関して擬一次反応(トリクロロ酢酸の量は，Fc 誘導体に比べて大 過剩である) であるとして計算した。

\section{3 結果と考察}

既報4)で述べたように，Fcおよびtーブチルフェロセン類の 1,2-ジクロロエタン溶媒中での酸化反応率の大きさの順位はつぎ のように観察されていた.

$\mathrm{Fc}<t$-BuFc $<1,1^{\prime}-$ di- $t$-BuFc $<1,1^{\prime}, 3$-tri- $t$-BuFc

$<1,1^{\prime}, 3,3^{\prime}-$ tetra- $t$-BuFc

これは, 電子供与性 $t$-ブチル基の数の增加により, 鉄原子の電 子密度が増加し，触媒プロトンが分子内鉄原子に配位しやすくな 
るためと考えられた，すなわち，この系の酸化反応性は，主に $t$-ブチル基の I-効果に支配されているものと考えられた.

同様の酸化反応を 1,4-ジオキサン溶媒中で行った結果も文献 4)に示したが, ここで, 式(1)の機構にしたがって起こる酸化

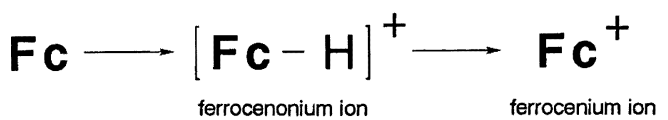

反応，すなわち，反応率の急激な増加（別の種類の反応）が始ま るまでの反応にのみ注目し, 各誘導体の反応速度定数を表 1 に 示す．ただし，Fcでは反応開始後 1 時間で反応率の急激な増加 が始をるので, 反応系中に $\mathrm{Fe}^{3+}$ の捕捉剤としてサリチル酸を共 存させて測定したデータを用いた. 表 1 より, 反応率の大きさ の順位はつぎのようであった。

$t$-BuFc $<1,1^{\prime}$-di- $t$-BuFc $<1,1^{\prime}, 3,3^{\prime}$-tetra- $t$-BuFc

\section{$<1,1^{\prime}, 3-$ tri- $t$-BuFc $<$ Fc}

この結果から，見かけ上の酸化反応率に関しては，置換基数との 相関関係は認められなかった。これは，1,4-ジオキサン中では， $t$-ブチル基が反応促進的にはたらくI一効果以外に何らかの抑制 効果もおよほしているためと推察される.

そこで，これら二つの効果(I-効果と抑制効果) がもっとも大 きいと考えられる $1,1^{\prime}, 3,3^{\prime}-$ テトラーt-ブチルフェロセンの酸化反 応を種々の溶媒中で行い, Fc のそれと比較することにより $t$-ブ チル基のI-効果および抑制効果の影響を検討した.

\section{1 ハロアルカン類溶媒中での反応}

Fc と $1,1^{\prime}, 3,3^{\prime}$-テトラ-t-ブチルフェロセンの酸化反応を, ク ロロホルム，1,1,1-トリクロロエタン，1,1,2,2-テトラクロロエ タン, ジクロロメタン，1,2-ジクロロエタン中で行った。これら

Table 1 The rate constants of ferrocene and $t$-butylferrocenes in 1,4-dioxane ${ }^{a, b}$ )

\begin{tabular}{lc} 
& $k \times 10^{6} / \mathrm{s}^{-1}$ \\
\hline Ferrocene $^{c)}$ & 40.9 \\
$t$-Butylferrocene & 5.25 \\
$1,1^{\prime}-$ Di- $t$-butylferrocene & 15.5 \\
$1,1^{\prime}, 3-$ Tri- $t$-butylferrocene & 28.2 \\
$1,1^{\prime}, 3,3^{\prime}-$ Tetra- $t$-butylferrocene & 18.4
\end{tabular}

a) Fc derivative : trichloroacetic acid $=1: 10(\mathrm{~mol}: \mathrm{mol})$.

b) Reaction temperature: $40^{\circ} \mathrm{C}$.

c) The measurement was carried out in addition of salicylic acid. (Fc : salicylic acid =1:1).
の反応速度定数を表 2 に示す. $1,1^{\prime}, 3,3^{\prime}$-テトラーt-ブチルフェロ センの反応性は，すべての溶媒中で，Fcのそれより高かった $\left(k_{\mathrm{tetra}}>k_{\mathrm{Fc}}\right)$. このことから，これらの系での酸化反応性は， 1,2-シクロロエタン中と同様に，主に $t$-ブチル基によるI-効果 に支配されていると考えられた。

表 2 に示した $k_{\mathrm{Fc}}$ および $k_{\mathrm{tetra}}$ の絶対值と誘電率の間にはなん ら相関はないが, 溶媒の誘電率 ${ }^{12)}$ と $\log \left(k_{\mathrm{tetra}} / k_{\mathrm{Fc}}\right)$ 値の間に相関 関係が見いだされた(図 1 口印)。 $\log \left(k_{\mathrm{tetra}} / k_{\mathrm{Fc}}\right)$ 値を用いること により相関が認められたのは，以下のように考えることができ る. $k_{\mathrm{Fc}}$ および $k_{\mathrm{tetra}}$ に対する影響要因として, 溶媒の誘電率によ る効果とそれ以外の要因による効果の二つが考えられる. 誘電率 以外の溶媒効果は， $k_{\mathrm{Fc}}$ と $k_{\mathrm{tetra}}$ の両者に対し同じ割合で影響をお よぼすと仮定すれば， $k_{\mathrm{tetra}}$ と $k_{\mathrm{Fc}}$ の比を用いることにより，誘電 率以外の要因による効果が互いに相殺され, 結果として誘電率に よる効果のみが残ったものと考えられた.

図 1 に示したように, $\log \left(k_{\mathrm{tetra}} / k_{\mathrm{Fc}}\right)$ 値は溶媒の誘電率の増加 により増大していた．この現象は，以下のように解釈されたす なわち，既報4)で述べたように，この酸化反応の律速段階は，式 (1)の最初の段階であり，Fc 誘導体の鉄原子へのプロトンの配 位のしやすさに支配されている. Fc と 1,1',3,3'-テトラ-t-ブチ ルフェロセンを比較すると, $t$-ブチル基の I-効果により後者の 鉄原子の電子密度の方が高く, より大きく分極していることにな

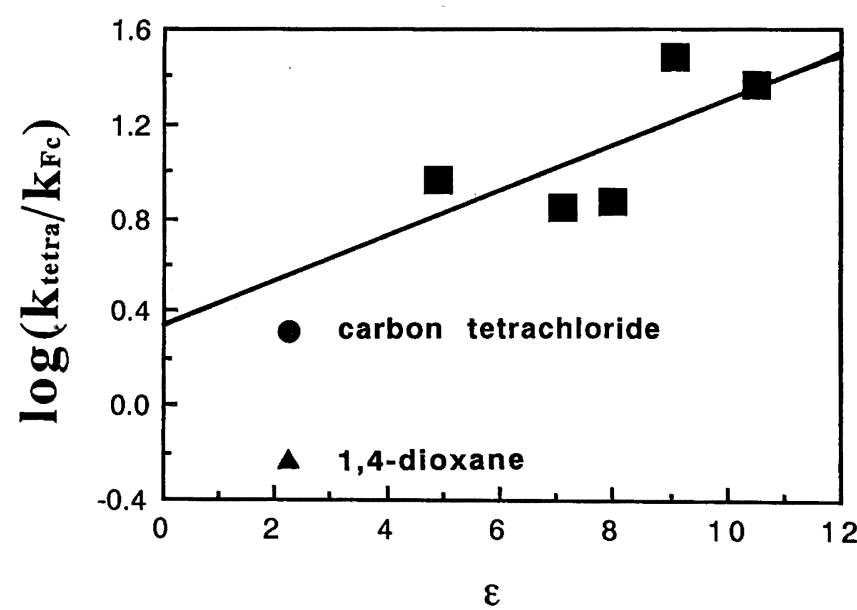

Fig. 1 Plot of $\log \left(k_{\text {tetra }} / k_{\mathrm{Fc}}\right)$ against $\varepsilon^{13)}$ of haloalkanes and 1,4-dioxane

Table 2 The rate constants of ferrocene and 1,1',3,3'-tetra-t-butylferrocene in haloalkanes and 1,4-dioxane ${ }^{a, b}$

\begin{tabular}{clcccc} 
Entry & \multicolumn{1}{c}{ Solvent } & $\varepsilon^{c)}$ & $k_{\mathrm{Fc}} \times 10^{5} / \mathrm{s}^{-1}$ & $k_{\text {tetra }} \times 10^{5} / \mathrm{s}^{-1}$ & \multicolumn{1}{c}{$\log \left(k_{\mathrm{tetra}} / k_{\mathrm{Fc}}\right)$} \\
\hline 1 & Chloroform & 4.9 & 1.92 & 17.6 & 0.96 \\
2 & 1,1,1-Trichloroethane & 7.1 & 1.11 & 3.93 & 0.85 \\
3 & 1,1,2,2-Tetrachloroethane & 8.0 & 4.66 & 37.9 & 0.87 \\
4 & Dichloromethane & 9.1 & 1.25 & 61.6 & 1.48 \\
5 & 1,2-Dichloroethane & 10.5 & 2.70 & 3.00 & 0.31 \\
6 & Carbon tetrachloride & 2.2 & 1.47 & 2.53 & -0.25
\end{tabular}

a) Fc derivative : trichloroacetic acid $=1: 270(\mathrm{~mol}: \mathrm{mol})$.

b) Reaction temperature: $30^{\circ} \mathrm{C}$.

c) Ref. 12). 
る4).このような分極は, 誘電率の高い溶媒中ではより促進され る. その結果, プロトン化が促進され $k_{\mathrm{tetra}} / k_{\mathrm{Fc}}$ の值が溶媒の誘 電率の増加に伴い大きくなったと考えられた。

この推定が正しければ，より小さな誘電率をもつ溶媒中では $\log \left(k_{\text {tetra }} / k_{\mathrm{Fc}}\right)$ 值はより小さくなると予想される. 事実, 他の溶 媒効果が同じで誘電率のみ小さいと思われる四塩化炭素溶媒中で 酸化反応を試みたところ, $\log \left(k_{\mathrm{tetra}} / k_{\mathrm{Fc}}\right)$ 値は著しく小さくな り, 図1 中にその值をプロットしてみると, 他のハロアルカン 溶媒を含め直線関係をほほ満足していた(図 1 ○印)。すなわち, この結果は，上述の結論(誘電率による効果) を支持するものと 判断される.

\section{2 含酸素溶媒中での反応}

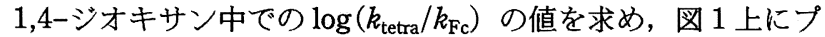
ロットした(図中 $\Delta$ 印).1,4-ジオキサンは, 四塩化炭素とほほ同 じ誘電率をもつにもかかわらず，その結果は，直線関係からずれ ていた。これは，1,4-ジオキサンの持つ誘電率以外の効果が $k_{\text {tetra }}$ と $k_{\mathrm{Fc}}$ に違った割合の影響をおよほしたことによると考えら れる。

誘電率以外の効果を検討するためには，誘電率の変化を小さく する必要がある，そのために，混合溶媒(1,2-ジクロロエタン: 極性溶媒 $=9: 1(\mathrm{~mol} / \mathrm{mol}))$ を用いて酸化反応を行った。このよ うな混合比では，溶媒の大部分が，1,2-ジクロロエタンであるた め, 混合溶媒の誘電率には，あまり影響を与えないと考えられ る13)。 また，これらの混合溶媒中では，今回の測定時間(1.5 時 間）中に，前報4で述べた Fc の急激な分解は始まらなかった。

これらの反応速度定数を表 3 に示す.

著者らは，含酸素溶媒の種々の性質の指標と， $k_{\mathrm{tetra}}$ および $k_{\mathrm{Fc}}$ との関係を検討した. その結果, 塩基性度 $(-p K a)^{14)}$ を溶媒の性 質の指標として用いることにより，エーテル系およびアルコール 系溶媒それそれれに対し直線関係が観察された(図 2)。エーテルと アルコール両系列に対する直線とも左下がりであり, $\log \left(k_{\text {tetra }}\right)$ $k_{\mathrm{Fc}}$ ) 值は, 塩基性の増加（-pKaの減少）とともに減少してい た. 特に，エーテル系列のテトラヒドロフラン(THF) または 1,4-ジオキサンとの混合溶媒中では, $\log \left(k_{\mathrm{tetra}} / k_{\mathrm{Fc}}\right)$ 值は負であ り，Fcの反応率がテトラ体のそれを上回っていた，すなわち， THF や 1,4-ジオキサン溶媒中では, I-効果や誘電率効果を上回

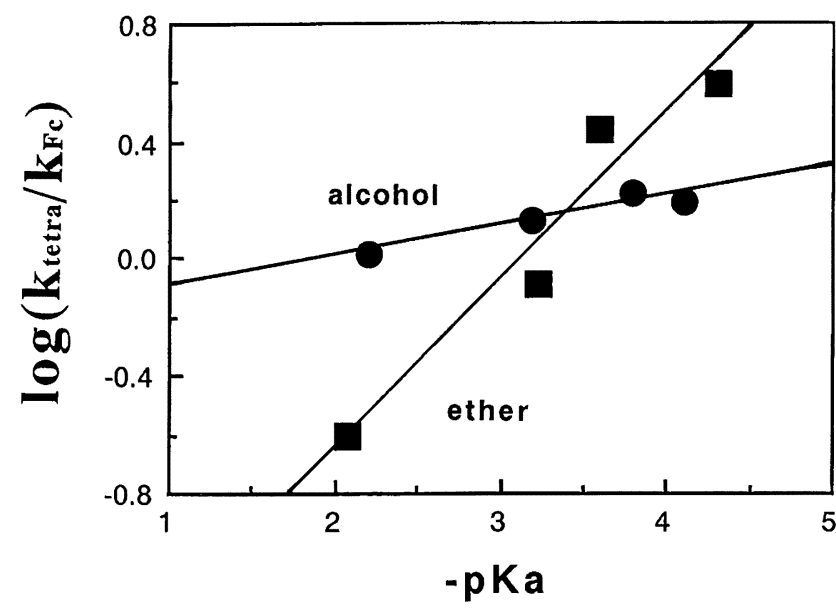

Fig. 2 Plot of $\log \left(k_{\text {tetra }} / k_{\mathrm{Fc}}\right)$ against $-p K a^{15)}$ of solvent

るような $t$-ブチル基による反応抑制効果が存在すると考えられ る.

エーテルおよびアルコール系溶媒中では, 一般に, 触媒(トリ クロロ酢酸）プロトンは溶媒和され，さらに溶媒和は，溶媒の塩 基性度の増加とともに強くなることが知られている15). 生じた 溶媒和プロトンの有効的な大きさは，ハロアルカン溶媒中にある プロトン（ほとんど溶媒和されていない）よりもかさ高いと考え られる.このような溶媒和プロトンの Fc 誘導体の鉄原子への攻 撃は， $1,1^{\prime}, 3,3^{\prime}$-テトラーt-ブチルフェロセンでは， $t$-ブチル基に よる大きな立体障害を受けると予想される．このため，かさ高い 溶媒和プロトンが鉄原子を攻撃しにくくなり，酸化反応は阻害さ れたと推察できる.THF あるいは 1,4-ジオキサンを含む混合溶 媒中で, $1,1^{\prime}, 3,3^{\prime}$-テトラーt-ブチルフェロセンの反応性は, 置換 基による立体障害の方が，そのI-効果による促進効果を上回っ て，Fcのそれよりも低くなったと考えられた。したがって， 1,4-ジオキサン溶媒中での $t$-ブチルフェロセン類の酸化反応性 の順序が，置換基数との間に相関関係を示さなかった結果（図 1) も，見かけ上の酸化反応性が，溶媒のI-効果や誘電率による促 進効果と, $t$-ブチル基による反応抑制效果の両者の総和として観 察されたためと解釈すれば理解することができる.

Table 3 The rate constants of ferrocene and 1,1',3,3'-tetra-t-butylferrocene in mixed solvents with $1,2-$ dichloroethane ${ }^{a, b, c)}$

\begin{tabular}{|c|c|c|c|c|c|}
\hline Entry & Solvent & $-p K a^{d)}$ & $k_{\mathrm{Fc}} \times 10^{6} / \mathrm{s}^{-1}$ & $k_{\text {tetra }} \times 10^{6} / \mathrm{s}^{-1}$ & $\log \left(k_{\text {tetra }} / k_{\mathrm{Fc}}\right)$ \\
\hline 8 & (Pure 1,2-dichloroethane) & - & 41.1 & 770.0 & 1.27 \\
\hline 10 & Tetrahydrofuran (THF) & 2.08 & 22.2 & 5.6 & -0.60 \\
\hline 12 & Diethyl ether & 3.59 & 21.1 & 57.8 & 0.44 \\
\hline 13 & $\mathrm{Di}(2$-propyl) ether & 4.30 & 15.6 & 60.0 & 0.59 \\
\hline 14 & Methanol & 2.2 & 24.4 & 25.6 & 0.02 \\
\hline 16 & 2-Methyl-2-propanol & 3.8 & 1.8 & 3.0 & 0.22 \\
\hline 17 & 1-Butanol & 4.1 & 16.7 & 25.6 & 0.19 \\
\hline
\end{tabular}

a) 1,2-Dichloroethane : solvent $=9: 1(\mathrm{~mol}: \mathrm{mol})$.

b) Fc derivative : trichloroacetic acid $=1: 90(\mathrm{~mol}: \mathrm{mol})$.

c) Reaction temperature: $40^{\circ} \mathrm{C}$.

d) Ref. 14). 


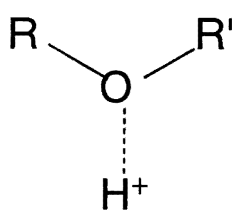

(a) Protonated ether

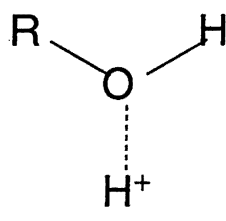

(b) Protonated alcohol
Fig. 3 protonated ether and alcohol

含酸素溶媒中での酸化反応性について，さらに検討してみる と, エーテル系とアルコール系溶媒に対する直線の傾きは異なっ ており(図 2)，エーテル系溶媒に対するそれの方が大きかった. この理由は，以下のように考えられる．図 3 に示すように，(a) エーテル系溶媒では $\mathrm{R}$ および $\mathrm{R}^{\prime}$ ともアルキル基であるのに対 し, (b)アルコール系溶媒では, 一つはアルキル基で他は水素原子 である. それゆえ，エーテル系溶媒で溶媒和されたプロトンの方 がアルコール系溶媒で溶媒和されたプロトンよりもかさ高いと考 えられる.このため, アルコール系溶媒の場合よりも, エーテル 系溶媒を含む混合溶媒中での方が， $t$-ブチル基による大きな立体 障害を示したと解釈できる.

\section{4 ま と}

(i) ハロアルカン類溶媒中での酸化反応に関しては,

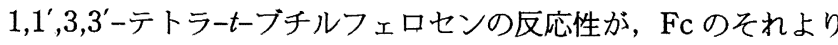
も高かった. 反応は, 反応促進的にはたらく $t$-ブチル基の I-効 果に支配されていた.すなわち，ハロアルカン中ではプロトンの 鉄原子への配位は, $t$-ブチル基による立体障害をほとんど受けて いないと判断された.

(ii) 誘電率の異なるハロアルカン溶媒中での $\log \left(k_{\mathrm{tetra}} / k_{\mathrm{Fc}}\right)$ 值 は誘電率との相関関係が認められた。これは，t-ブチル基による I一効果により, 分極している化合物ほど, 誘電率の高い溶媒中で はより強く分極しプロトン化されやすくなるためと考えられた.

(iii) THF あるいは 1,4-ジオキサンのような含酸素溶媒を含む 混合溶某中では， 1, 1',3,3'-テトラーt-ブチルフェロセンの反応性 は，Fcのそれよりも低かった。すなわち，これらの溶媒中では，
触媒プロトンが，溶媒和されてかさ高くなると考えられる．その ため, $1,1^{\prime}, 3,3^{\prime}$-テトラーt-ブチルフェロセンの鉄原子への溶媒和 プロトンの攻撃に対し， $t$-ブチル基によるI-効果や誘電率によ る反応促進効果を上回って立体障害が反応抑制効果として表れた と推察された.

(iv) この抑制効果は，エーテル系溶媒中での方がアルコール系 溶媒中よりも著しかった. 溶媒和プロトンの実効的な大きさは， エーテル系溶媒中の方がアルコール系溶媒中よりも大きいと考え られるためである。したがって，溶媒和プロトンのかさ高さと反 応抑制効果とが比例関係を示していることになり，この反応抑制 効果はおもにt-ブチル基による立体効果と解积すれば，これらの 結果を説明できる.

1）この報文を“フェロセン誘導体に関する研究(第11報) とする.

2）前報(第10報)，林 隆俊，岡田 豊，福地 毅，日化， $1994,340$.

3) Y. Okada, N. Yamamoto, T. Hayashi, Bull. Chem. Soc. Jpn., 62, 114(1989).

4) T. Hayashi, Y. Okada, T. Yamashita, Bull. Chem. Soc. Jpn., 64, 485(1991).

5) T. E. Bitterwolf, A. C. Ling, J. Organomet. Chem., 40, C29 (1972).

6) A. A, Koridze, P. V. Petrovskii, E. I. Fedin, A. I. Mokhov, J. Organomet. Chem., 96, C13(1975).

7) H. C. Brown, W. H. Bonner, J. Am. Chem. Soc., 76, 605(1954); C. D. Cook, J. Chem. Educ., 32, 312(1955).

8) T. Leigh, J. Chem. Soc., 1964, 3294.

9) T. S. Abram, W. E. Watts, Synth. React. Inorg. Met-Org. Chem., 4, 355.(1974).

10) M. Rosenblum, R. G. Woodward, J. Am. Chem. Soc., 80, 5443 (1958).

11）岡田豊, 中井昇, 中村尚武, 林隆俊, 日化, 1987, 1567.

12) J. A. Riddick, W. B. Bunger, "Organic Solvents", WileyInterscience (1970).

13) Y. Y. Akhadov, "Dielectric Properties of Binary Solutions", Pergamon Press(1981) p. 73, p. 86.

14) E. M. Arnett, C. Y. Wu, J. Am. Chem. Soc., 84, 1648(1962) ; 有機合成化学協会編，“溶剂ポケットブッ ク”，オーム社 (1967) p. 97.

15）戸倉仁一郎, “溶媒和”，化学同人(1972) p. 53.

\section{Steric Effect of $t$-Butyl Groups and Solvent Effect on the Oxidation Reaction of $t$-Butylferrocenes ${ }^{\dagger}$}

\section{Takatoshi HAYASHI, Yutaka OKADA* and Tetsurou YAMASHITA \\ Department of Chemistry, Faculty of Science and Engineering, Ritsumeikan University; Noji-cho, Kusatsu-shi 525 Japan}

The oxidation reactivity of ferrocene and $1,1^{\prime}, 3,3^{\prime}$-tetra-t-butylferrocene with air was measured in several solvents in the presence of trichloroacetic acid. In chloroalkanes, the $k_{\mathrm{tetra}} / k_{\mathrm{Fc}}$ depended on dielectric constant of solvent, suggesting the increasing polarization due to the I-effect of $t$-butyl group. In dichloroethane-ethers or dichloroethane-alcohols, a linear correlation between $k_{\mathrm{tetra}} / k_{\mathrm{Fc}}$ and $-p K a$ of ethers or alcohols was observed. This is probably because the bulky $t$-butyl group on the cyclopentadienyl ring hinders the protonation of iron atom by the solvated proton.

\footnotetext{
${ }^{\dagger}$ Studies on Ferrocene Derivatives, XI.
} 